\title{
Rainwater harvesting as alternative source for wudlu water in Indonesia
}

\author{
Gatot Eko Susilo ${ }^{1}$ \\ ${ }^{1}$ Civil Engineering Dept., Universitas Lampung, Bandar Lampung, 35145, Indonesia \\ gatot89@yahoo.ca
}

Received 01-08-2018; revised 31-08-2018; accepted 24-09-2018

\begin{abstract}
Indonesia is the country with the largest Muslim population in the world. And as a country with Muslim big population clean water for wudlu or purification must be available. Rainwater holds potential as an alternative source of wudlu water. Rainwater harvesting (RWH) for religious water supply is still very rare studied. Based on this, the research in this paper aims to calculate the potential supporting capacity of rainwater as an alternative source of wudlu water. Supporting capacity of rainwater harvesting (SCRWH) in this study was calculated by simulating inflow and outflow behavior at a rainwater harvesting facility in a mosque. Case study takes place at Nurul Iman Mosque in Southern Lampung. The mosque has an area of $168 \mathrm{~m}^{2}$ and able to accommodate 300 worshipers. Research show that the most effective reservoir size in the RWH facility in the observed mosque is between 15 to $30 \mathrm{~m}^{3}$ with SCRWH for wet years between $65 \%$ and $70 \%$ and for dry years between $44 \%$ and $53 \%$, respectively. The availability of wudlu water in a mosque basically cannot be expected $100 \%$ comes from rain water only. In the application of RWH in a mosque the maintenance of the RWH facility must be undertaken well.
\end{abstract}

Keywords: Rainwater harvesting, alternative source, Muslim, wudlu water.

\section{Introduction}

Indonesia is a country rich in natural resources, including water resources. The sources of water in Indonesia are mostly from forest areas, mountains, and areas that have a high intensity of rainfall. These water sources then flow into rivers and lakes or other bodies of water that many people use to meet daily needs. Based on the release issued by Map of the World in 2014 Indonesia is still included in the category of 10 countries that have the largest freshwater reserves in the world. In the release, Indonesia was ranked 7th with freshwater reserves of 2019 billion cubic meters. This position is still above India, Peru, and Venezuela whose reserves are slightly below 2000 billion cubic meters [6]. Nevertheless, Indonesia is still overshadowed by the future crisis of water supply. As a developing country whose population is growing rapidly from year to year, the need for clean water is also always increasing dynamically. On the other hand, the existence of water sources increasingly more threatened by human activities themselves. This causes a limited amount of water that can be utilized for life. Deforestation causes flooding in the rainy season and drought in the dry season. At the same time, the continuous water pollution by industry and human activities makes more and more fresh water waste and unusable. 
To face the future water supply crisis, environmental improvement needs to be done. The replanting of critical forests, restoration and maintenance of rivers, and community empowerment for the environment are methods that can be taken to preserve water quality and quantity. However, dynamic population growth still requires us to seek other water sources as an alternative source of water that can meet the needs of freshwater for the community. As a country whose bulk rainfall is quite large, around 2000 to $3000 \mathrm{~mm} /$ year [11], rainwater harvesting (RWH) is a viable option. RWH has been adopted and developed in many parts of the world where conventional water supply systems can no longer meet the water needs of the people [3]. RWH is basically a human activity for collecting and storing rainwater from various catchment areas such as roofs or other surfaces. RWH is an alternative to renewable clean water and is ideal for fulfilling domestic water supply [1].

Based on the CIA World Factbook, the total population of Indonesia in 2015 is 255.64 million people. With that amount, Indonesia became the fourth most populous country in the world after China, India, and the United States. Of the total population, about $87 \%$ of the Indonesian population is Muslim. At the present time Indonesia is a country with the largest Muslim population in the world. As a predominantly Muslim country, one of the freshwater needs in the future is the need for water for Islamic worship (wudlu). Based on the literal translation, wudlu means clean and beautiful. While doing wudlu means using water on certain limbs in certain ways to remove mild dirt on the body. Based on Islam, wudlu is one of the requirements for the validity of prayer. Or in other words people who pray without wudlu then the prayer are not valid. Physically, the procedure of doing wudlu begins by washing both hands from the wrist up to the fingertips. This step is continued with gargling to clean the mouth. Further step is washing the inside of the nose until clean. The next procedure is to wash the whole face and proceed with washing hands from elbows to fingertips. Wudlu continued by wiping the forehead up to the crown of the head. The final part of the wudlu is to clean the ears thoroughly and wash the feet from the soles of the feet to the top of each ankle. Every step is undertaken three times and should be done in sequence. The water requirements for each person's wudlu vary depending on the culture and availability of water. Based on the Ministry of Public Works of the Republic of Indonesia, the per capita wudlu water requirement is 16.2 liters per day. If this amount is divided by the number of prayers 5 times a day then this means a Muslim need 3.24 liters of water for each wudlu.

Water used for wudlu is clean fresh water and water that can be used for wudlu according to Islam is: rain water, sea water, water coming out of the spring-water, well water, river water, dew and snow. Sea water is the greatest potential for wudlu water. But rarely people use sea water for wudlu because of psychological factors. The choice for other wudlu water sources is rain water. With considerable intensity every year in Indonesia, rain water can be used as alternative source of wudlu water besides well water and river water commonly used during this time. Although Indonesia has significant rainfall intensity every year, the application of rainwater harvesting to be used as wudlu water has not been so popular. Though actually began to appear some mosques began to lack wudlu water for the congregation.

Rainwater harvesting (RWH) is an activity to catch rainwater on a surface and channel it to be stored and used for various purposes. In countries rich in water, RWH facilities are made to conserve ground water. In arid or dry countries, RWH is applied to seek alternative domestic water sources. Rainwater utilization through the application of RWH for religious water supply is still very rare. Based on this, the research in this paper aims to calculate the potential supporting capacity of harvesting rainwater as an alternative source of wudlu water. Supporting capacity of rainwater harvesting in this study was calculated by simulating inflow and outflow behaviour at a rainwater harvesting facility in a mosque.

\section{Material and Methods}

a. Rainwater harvesting facility for wudlu water supply

In general, basic rainwater harvesting facilities (RWH) in a building consists of four parts. The first part is the rain catching section. This part of the water catchment area is the roof of the building. The 
second part is the collecting and sending part of the rainwater. This section is responsible for collecting and sending rainwater from the catchment area to the reservoir. The third part is the rainwater storage section. This section is a reservoir that stores rainwater collected before use. The fourth part is the distribution. This section is in the form of pipes and pumps that function to distribute water from the reservoir to the service area. Filters are a secondary part of an RWH facility. Filters are installed in the rainwater collection section to separate the rainwater with debris and downstream of the reservoir to separate the rain water with fine dirt and remove the odor. The RWH facility in the mosque for wudlu water supply is not much different from the basic facilities of RWH. Illustration of RWH facility in the mosque for wudlu water supply can be seen in the following figure:

\section{b. Supporting capacity of rainwater harvesting}

To assess the success of a rainwater harvesting (RWH) application in a building, it is necessary to calculate the supporting capacity of the RWH (SCRWH). SCRWH is the ratio between the days whose water requirements can be met by RWH with the total number of days in a year. SCRWH ranges from 0 to $100 \%$. For example, a building in 2012 has a SCRWH of $50 \%$, meaning that within year 2012 the RWH of the building is capable of supplying water for 183 days from all days of the year (366 days). SCRWH is highly dependent on the intensity of annual rainfall and the dimensions of rainwater storage reservoirs. To obtain the SCWRH value, a water balance simulation involving the Inflow, Outflow and Storage relationships must be performed. In detail the formula in RWH simulation is given as $[4,5,7,8,9,10]$ :

$$
\text { St }=\text { St- } 1+\text { It }- \text { Ot for } \quad 0<\text { St }<\text { Smax }
$$

where:

$$
\begin{array}{lll}
\text { St } & = & \text { reservoir volume on day } \mathrm{t}\left(\mathrm{m}^{3}\right) \\
\text { St-1 } & = & \text { reservoir volume on day } \mathrm{t}-1\left(\mathrm{~m}^{3}\right) \\
\mathrm{It} & = & \text { inflow on day } \mathrm{t}\left(\mathrm{m}^{3}\right) \\
\mathrm{Ot} & = & \text { is outflow on day } \mathrm{t}\left(\mathrm{m}^{3}\right) \\
\text { Smax } & = & \text { maximum storage capacity }\left(\mathrm{m}^{3}\right) .
\end{array}
$$

The inflow is formulated as follows

$$
\text { It }=\text { c.Rt.A. } 1000
$$

where:

c $=\quad$ runoff coefficient for roofs, the range value is ranged between 0.8 and 1.0 [2]

$\mathrm{Rt} \quad=\quad$ volume of rainfall on day $\mathrm{t}(\mathrm{mm})$

A $=$ the area of roof $\left(\mathrm{m}^{2}\right)$.

The outflow for day $\mathrm{t}$ is calculated using formula below:

The outflow is formulated as follows

$$
\mathrm{Ot}=\mathrm{nD}
$$

$\begin{array}{lll}\mathrm{n} & = & \text { number of building occupants } \\ \mathrm{D} & = & \text { water demand per person per day }\end{array}$

If the reservoir volume on day $t$ is greater than 0 then that day is considered as the day whose water demand has been fully supply by rainwater. 


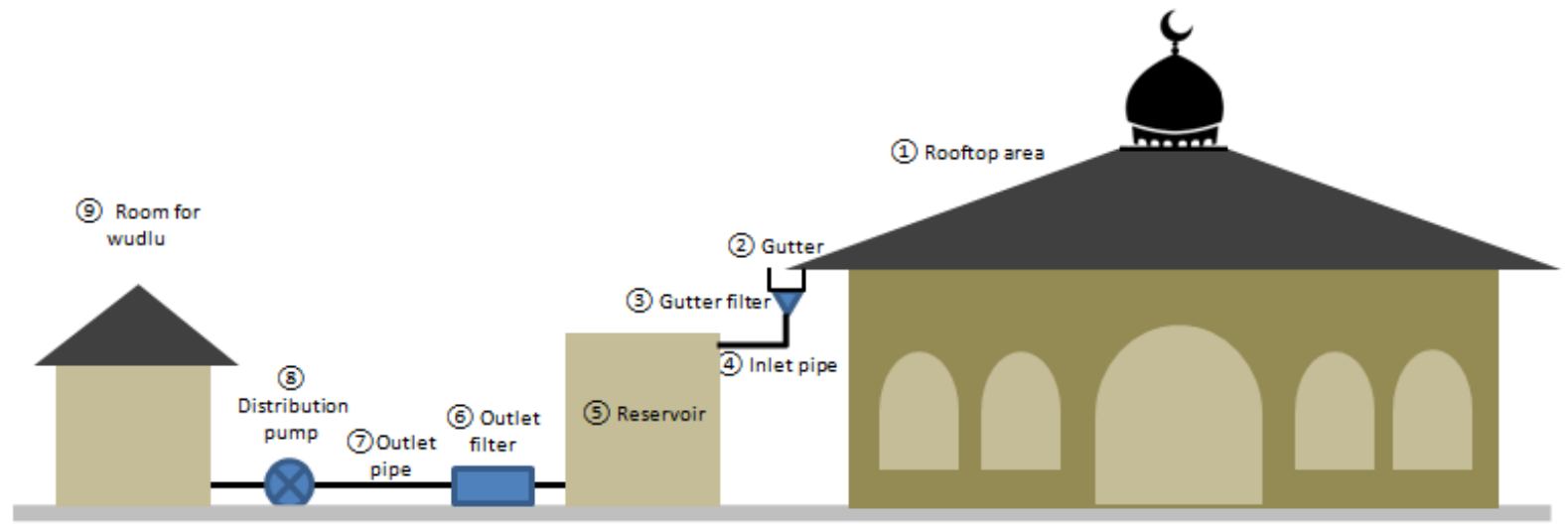

Figure 1. RWH facility in the mosque for wudlu water supply

\section{c. Case study}

The case study in this research takes place at Nurul Iman Mosque which is located in Dusun II of Sindangsari, Natar Village, Natar District, South Lampung Regency. The mosque is a building with an area of $168 \mathrm{~m}^{2}$, two storeys, and able to accommodate as many as 300 worshipers. The first floor of the mosque is used for prayers and the second floor is the study room and library. Rainfall data is taken from Branti Airport located not far from the study location.

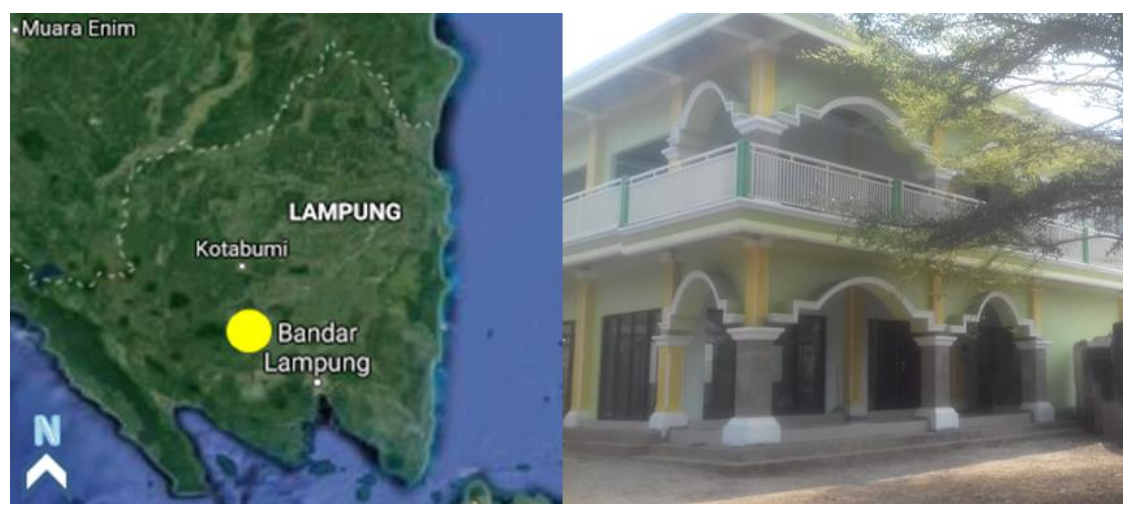

Figure 2. Location of study

The data used in this study is the daily rainfall data of 2015 and 2016. Year 2015 is considered to represent a dry year because annual rainfall is less than $2000 \mathrm{~mm}(1628.1 \mathrm{~mm})$. Year 2016 is considered to represent the wet year because its annual rainfall is more than $2000 \mathrm{~mm}(2317.6 \mathrm{~mm})$. The performance of the data is given in Figure 3 below.

The simulation for calculating SCRWH is done with the following data:

- Each wudlu every pilgrim spends about 5 liters of water.

- Every day there are 5 times of prayer: Isya, Subuh, Zuhur, Ashar, and Maghrib.

- At every Isya prayer number of mosque pilgrims is $15 \%$ of the mosque's maximum capacity

- At every Subuh prayer the number of pilgrims is $5 \%$ of the mosque's maximum capacity

- At every Zuhr prayer the number of mosque worshipers is $10 \%$ of the mosque's maximum capacity

- At every Asr prayer the number of mosque worshipers is $5 \%$ of the mosque's maximum capacity

- At every Maghrib prayer the number of mosque worshipers is $20 \%$ of the mosque's maximum capacity 
- On every Friday every Zuhr prayer the number of mosque pilgrims is $100 \%$ of the mosque's maximum capacity

- In every year there are two prayers of the feast that is held by the pilgrims who number $100 \%$ of the mosque's maximum capacity

Especially in the month of Ramadan, the congregation of the mosque changed to:

- At every Isya prayer number of mosque pilgrims is $60 \%$ of the mosque's maximum capacity

- At every Subuh prayer the number of pilgrims is $20 \%$ of the mosque's maximum capacity

- At every Zuhr prayer the number of mosque worshipers is $20 \%$ of the mosque's maximum capacity

- At every Asr prayer the number of mosque worshipers is $20 \%$ of the mosque's maximum capacity

- At every Maghrib prayer the number of mosque worshipers is $60 \%$ of the mosque's maximum capacity

Based on the data above, the wudlu water demand at the Nurul Iman Mosque during the years 2015 and 2016 is given in Figure 4.

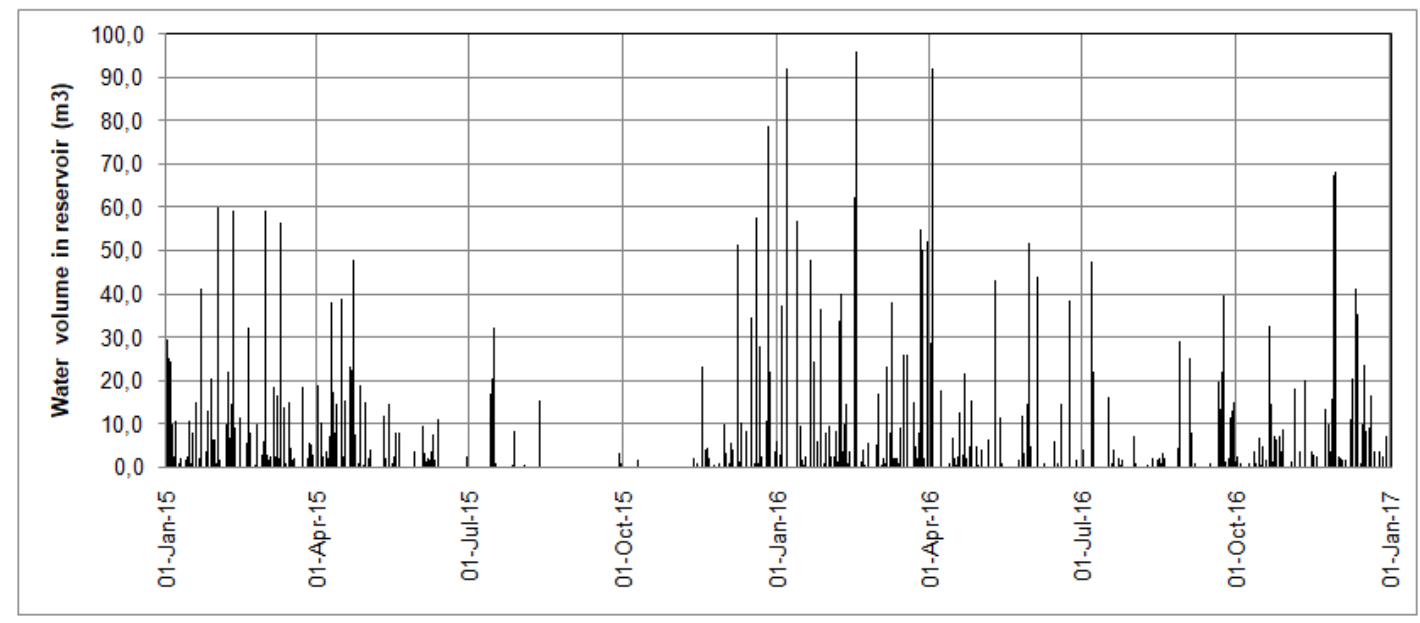

Figure 3. Daily rainfall data of Branti Airport for year 2015 and 2016

\section{Result and Discussion}

Simulations are operated using reservoir dimensions that vary from 4 to $50 \mathrm{~m}^{3}$. Figure 5 shows the SCRWH generated by various reservoir dimensions. The graph also shows that the most effective reservoir dimension is between 15 to $30 \mathrm{~m}^{3}$ with SCRWH for wet years between $65 \%$ and $70 \%$ and for dry years between $44 \%$ and $53 \%$, respectively. If the middle value is drawn then the most effective reservoir dimension is $22.5 \mathrm{~m}^{3}$ with SCRWH $67.5 \%$ and $50.5 \%$ for wet and dry years, respectively. The fluctuation of water volume in the reservoir based on this reservoir dimension is presented in figure 6. Figure 6 shows that from December to June the reservoir is always filled with water in both wet and dry years. In the dry year the reservoir will have minimum water savings in mid-June to midDecember. In the wet year the minimum water savings occur only during the peak of the dry season in mid-July to mid-September. Worship done in the month of Ramadan in Nurul Iman Mosque requires wudlu water is greater than the other months. Ramadan is one of the months on the Islamic calendar. In this month all Muslims perform fasting and other more intensive worship in the mosque. The Arabic calendar has a different time calculation with the International calendar based on the calculation of the Christian calendar. Therefore, the commencement of the month of Ramadan each year is also different on the International calendar. This will also affect the water volume of the RWH 
reservoir. If the month of Ramadan falls in the rainy season then the influence on the fluctuation of water volume in RWH reservoir will not be too large. Conversely, if the month of Ramadan falls in the dry season then the volume of water in the reservoir RWH will reach a minimum point.

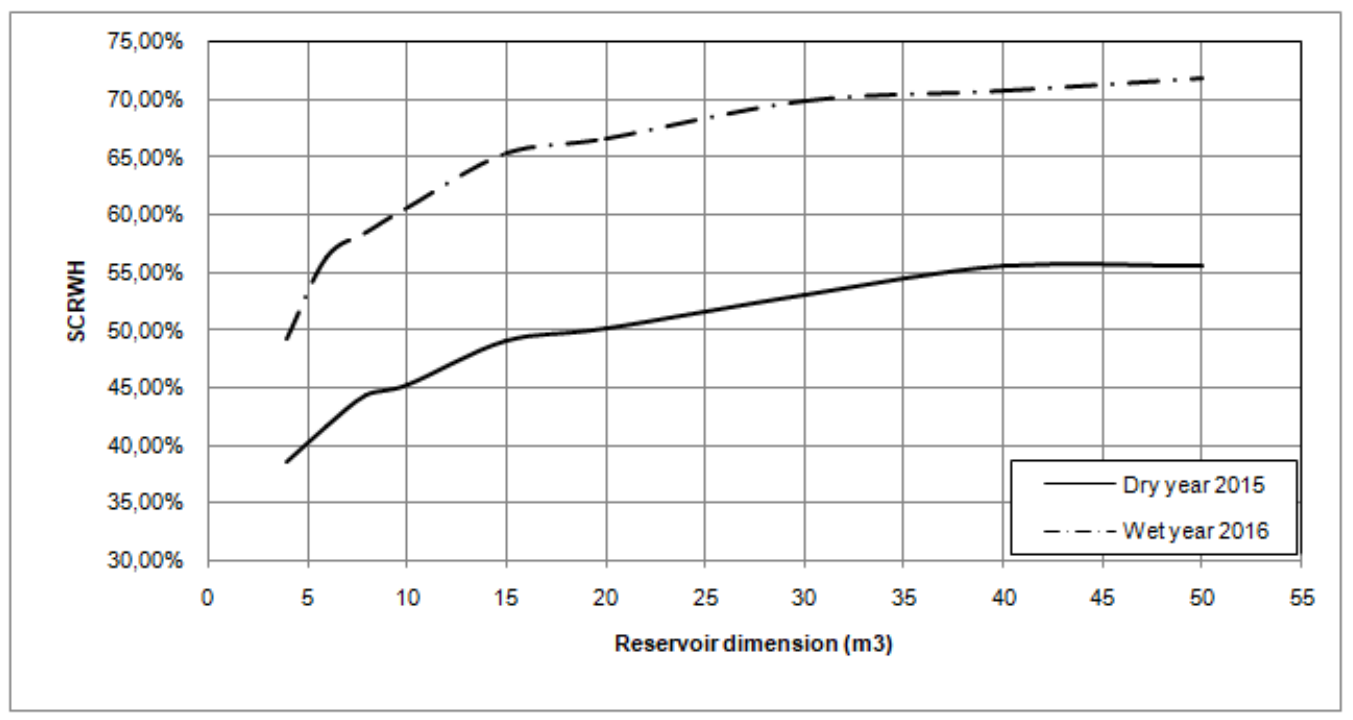

Figure 4. SCRWH generated dimension from the simulation using various reservoir dimensions

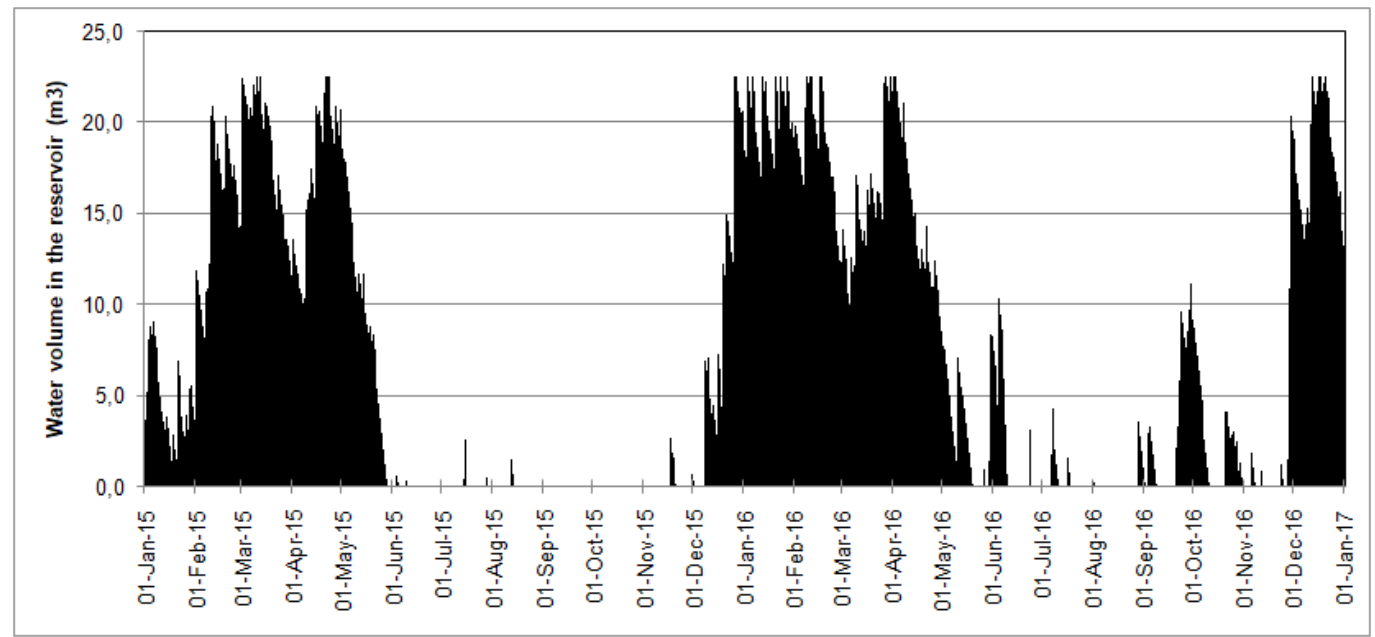

Figure 5. The fluctuation of water volume in the reservoir using $22.5 \mathrm{~m}^{3}$ reservoir dimensions

SCRWH of Mosque Nurul Iman will become even greater if not everyone takes wudlu water in the mosque. Based on field surveys on Friday or prayer in Ramadhan, only 30\% of pilgrims take wudlu water in the mosque. The rest of the pilgrims have done wudlu first in their homes. Based on these circumstances, the SCRWH of Nurul Iman Mosque will be $58.90 \%$ and $82.79 \%$ for dry year and wet year, respectively, with a reservoir dimension of $22.5 \mathrm{~m}^{3}$.

Land availability is a matter to consider in making the RWH reservoir. Reservoirs with dimensions of $22.5 \mathrm{~m}^{3}$ can be built in various shapes. Reservoirs can be built on the ground, underground, or partly above the ground and partially underground. Taking into account the area of land available in Masjid Nurul Iman, the following recommended sizes for reservoirs with these dimensions are:

- Reservoir with length $4 \mathrm{~m}$, width $3 \mathrm{~m}$ and height $2 \mathrm{~m}$ (volume $24 \mathrm{~m}^{3}$ ) 
- Reservoir with length $5 \mathrm{~m}$, width $2 \mathrm{~m}$ and height $2,5 \mathrm{~m}$ (volume $25 \mathrm{~m}^{3}$ )

- Reservoir with length $4 \mathrm{~m}$, width $2 \mathrm{~m}$ and height $3 \mathrm{~m}$ (volume $24 \mathrm{~m}^{3}$ )

- Reservoir with length $3 \mathrm{~m}$, width $3 \mathrm{~m}$ and height $2,5 \mathrm{~m}$ (volume $22,5 \mathrm{~m}^{3}$ )

Reservoir should be made of masonry plates or of thin concrete (ferrocement). Reservoir should also be coated with anti-leaking paint to avoid water seepage and leaks. Reservoir should also be equipped with facilities for maintenance such as manhole, stairs, and drainage holes.

The availability of wudlu water in a mosque basically cannot be expected $100 \%$ comes from rain water only. In dry seasons, reservoirs must be filled with well water or ground water to avoid deficiency of wudlu water. To maintain the availability of wudlu water, people around the mosque should not take water from the mosque for daily necessities such as for bathing, washing, and sanitary purposes. Another important thing to note in the application of RWH in a house of worship is the maintenance of the RWH facility itself. Maintenance must be done periodically to maintain the smooth operation of RWH facilities. In a mosque surrounded by many trees, gutters are components that must be taken care of. The falling leaves that accumulate in the gutter will make the drainage channel become clogged and the rainwater cannot flow into the reservoir.

\section{Conclusions}

The potential support of rainwater as an alternative source of wudlu water in Indonesia has been discussed above. The conclusion is that rainwater can be used as an alternative source of clean water in the future to supply various water needs including wudlu water needs. Harvesting of rainwater in the mosques for wudlu water use in Indonesia is still rare. Therefore, it is time to introduce rainwater harvesting system in order to overcome the clean water crisis, especially for wudlu, in the future. Rainwater harvesting technology is not a difficult and expensive technology. There is no need for an expert in constructing a rainwater harvesting facility. The important thing to remember from a rainwater harvesting application is the maintenance of the rainwater harvesting facility itself. Maintenance must be done periodically to maintain the smooth operation of RWH facilities

\section{Acknowledgements}

The author wishes to convey his infinite gratitude to the Department of Civil Engineering, Lampung University for his support of this research. The authors also wish to express their gratitude to the students who assisted with the completion of this research.

\section{References}

[1] Abdulla, F. A., and Al-Shareef, A. W. 2009. Roof rainwater harvesting systems for household water supply in Jordan. Desalination, 243:195-207.

[2] Fewkes A. 1999. The use of rainwater for WC flushing: the field testing of a collection system. Building and Environment, 34(6), 765-772.

[3] Handia, L., Tembo, J. M., and Mwiindwa, C. 2003. Potential of rainwater harvesting in urban Zambia. Physics and Chemistry of the Earth, Vol. 28:893-896.

[4] Kahinda JM, Taigbenu AE, and Boroto RJ. 2010. Domestic rainwater harvesting as an adaptation measure to climate change in South Africa. Physics and Chemistry of the Earth, Vol. 32(15-18), pp. 1050-1057.

[5] Khastagir A, and Jayasuriya N. 2010. Optimal sizing of rain water tanks for domestic water conservation. Journal of Hydrology, 381(3-4), pp. 181-188.

[6] Map of the World, 2017. Top Ten Countries with the Largest Renewable Water Supply. Website: https://www.mapsofworld.com/world-top-ten/world-top-ten-fresh-water-supplymap.html.

[7] Poedjiastoeti H, and Syahputra B. 2006. Determination of the maximum peak hour and daily maximums on the domestic water use pattern in Kalasan, Sleman, Yogyakarta. Proceeding of Lecturer Research, Research Institute of Sultan Agung University, Yogyakarta, Indonesia.

[8] Susilo GE, Yamamoto K. and Imai T. 2011. The identification of rainwater harvesting potency 
in supporting freshwater availability under the effect of El Nino. Proceeding IWA - ASPIRE International Conference, October 2011, Tokyo - Japan.

[9] Susilo GE. 2015. Experience in rainwater harvesting application at household scale in Bandar Lampung, Indonesia. Proceeding of The 1st Young Scientist International Conference of Water Resources Development and Environmental Protection, Malang, Indonesia, 5-7 June 2015

[10] Susilo GE, Efendi R, Desmawati E, and Nalaralagi A. 2017. Promoting rainwater harvesting as an alternative of freshwater source for public sanitation. Journal of Asian Institute of Low Carbon Design (2017), pp. 201-207.

[11] Widyanti, E. 2015. Curah hujan Indonesia, Pengembangan Media Pembelajaran Geografi. Website: http://eka-widiyanti.blogspot.co.id/2015/04/curah-hujan-indonesia.html. 25 January 2018 (20.30 WIB). 